\title{
The impact of workplace placement on students' entrepreneurial attitude
}

\author{
by Manning, L. and Parrott, $P$.
}

Copyright, Publisher and Additional Information: This is the author accepted manuscript. The final published version (version of record) is available online via Emerald Publishing

Please refer to any applicable terms of use of the publisher.

DOI: https://doi.org/10.1108/HESWBL-05-2017-0030

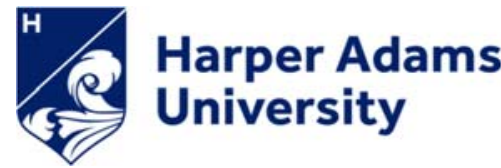




\section{Emerald $\begin{aligned} & \text { Higher Education, Skills } \\ & \text { and Work-Based Learning }\end{aligned}$}

\section{The impact of workplace placement on students' entrepreneurial attitude}

\begin{tabular}{|r|l|}
\hline Journal: & Higher Education, Skills and Work-Based Learning \\
\hline Manuscript ID & HESWBL-05-2017-0030.R2 \\
\hline Manuscript Type: & Research Paper \\
\hline Keywords: & $\begin{array}{l}\text { Entrepreneurial legacy, entrepreneurial attitude, entrepreneurial, bridging, } \\
\text { entrepreneurial intention, subjective norms }\end{array}$ \\
\hline \multicolumn{2}{|l}{} \\
\hline
\end{tabular}

SCHOLARONE ${ }^{m}$

Manuscripts 
2 Abstract

3 Purpose: The aim of the research was to determine the impact of a workplace placement on

4 the student participants' self-reported entrepreneurial attitude (EA)

5 Design/methodology/Approach: A review of relevant literature informed questions

6 incorporated in the university's annual feedback questionnaire completed by students $(\mathrm{n}=$ 7 461) on return from a work placement of between 44 and 52 weeks.

8 Findings: The study has shown that both gender and entrepreneurial legacy influence 9 baseline and post-placement EA $(\mathrm{p}<0.05)$. The interaction between EA, social learning, 10 perceived behavioural control (PBC), subjective norms and perceived relational support 11 (PRS) was also considered.

12 Originality/Value: This research provides context for further qualitative work in this area, 13 especially the influence of gender and entrepreneurial legacy on reported baseline EA and EA 14 post work placement and will inform pedagogical development in terms of embedding 15 entrepreneurial teaching in future curriculum development at the university.

17 Key words

18 Entrepreneurial legacy, entrepreneurial attitude, subjective norms, entrepreneurial bridging, 19 entrepreneurial intention 


\section{Introduction}

23 Although entrepreneurial behaviour is seen as an asset within the sector (Lans et al., 24 2015), agriculture has been considered as an inflexible, low-tech industry dominated by 25 family businesses that are mostly focused on doing things better rather than doing new things. 26 Indeed, entrepreneurship is vital for economic transformation, stimulation of global 27 development and is a wealth generator at individual, regional, national and international levels 28 (Obembe et al., 2014). Social and economic constructs mediate entrepreneurial activity. 29 Social factors that are of influence can be cultural, political, or policy orientated, and 30 consideration of rural entrepreneurship encompasses innovative activity to meet socio31 economic issues such as food security, population growth, urbanisation, freshwater use, and 32 effective soil management as well as those social issues affecting rural communities and 33 places. Korsgaard et al., (2015) differentiate between entrepreneurship in the rural i.e. profit34 oriented entrepreneurial activities with limited embeddedness in the wider rural social 35 community and rural entrepreneurship meaning entrepreneurial activities that leverage local 36 resources to re-connect place with space. An entrepreneurial mindset affords business 37 operators the ability to take advantage of opportunities and also ensure their businesses 38 remain viable and resilient to regulatory, market or environmental shocks especially important 39 where businesses are connected to the land.

40 1. Factors that influence student entrepreneurialism

41 The term entrepreneurship pertains to the actions of a risk taker, undertaking a creative 42 venture into a new business or reviving an existing business with notions of individuals being 43 seen as having characteristics of individualism, drive, intuition, being highly motivated, 44 creative, and energetic (Ehrlich, 1986; Hébert and Link, 1988; Obembe et al. 2014). 45 Entrepreneurship has become a key subject in secondary and tertiary education, offering 
46 promise for multiple stakeholders (Dahalan et al. 2013; Ishmail et al. 2015; Mat et al. 2015).

47 Students that come from farming families or families high levels of parental self-employment

48 iwill have experienced social learning (SL) through their family social context or situation.

49 Jaskiewicz et al. (2015:30) describe entrepreneurial legacy as "rhetorically reconstructed

50 narratives of the family's past entrepreneurial behaviour or resilience that motivate and give

51 meaning to entrepreneurship". Thus these students have grown up within a narrative of self-

52 employment, and this may well influence their thinking, attitudes and potentially their

53 behaviour. Indeed, entrepreneurial legacies, such as those derived from being involved with a

54 farming business from birth, are "imprinted in children through active involvement in the

55 family firm and through story telling within large and cohesive families" (Jaskiewicz et al.

56 2015). Further, the social aspects of the extended family construct leads to entrepreneurial

57 bridging that nurtures entrepreneurship in younger generations as multiple generations work

58 side by side in the family business. Families with an entrepreneurial legacy may also nudge

59 their children toward educational settings and work experiences that are perceived as being of

60 high value with regard to the degree of entrepreneurial knowledge and information (EKI)

61 embedded in the learning experience, especially if previous generations of the family have

62 attended the same establishment. There is therefore, in these families, a focus on context

63 specific learning i.e. that the learning is related to the operations within the family business in

64 terms of skills accumulation which can enrich the family business. Thus students may

65 gravitate towards entrepreneurial universities that can provide educational setting and work

66 setting experiences in the form of industry placements, scholarship opportunities and wider

67 industry related activities. The families in turn will then provide the social and relational

68 support and financial capital to underpin the next generation's entrepreneurial activity.

69 Ambad and Damit (2016) conclude that three factors influence entrepreneurial intention:

70 entrepreneurial attitude (EA) the greater the students' attitude to entrepreneurship, the greater 
71 the entrepreneurial intention; perceived behavioural control $(\mathrm{PBC})$ the easier the student

72 thought it would be to become an entrepreneur the more motivated they were to be 73 entrepreneurial themselves; and perceived relational support (PRS) in that the greater the 74 support from people around them e.g. parents, family, friends, network, the greater the 75 student's intention to be entrepreneurial. Camelo-Ordaz et al., (2016) consider entrepreneurial 76 self-efficacy, a concept derived from Social Learning Theory (SLT), whilst others have 77 described this characteristic as entrepreneurial orientation (EO), see Ishmail et al., (2015).

78 Self-efficacy reflects an individual's perception of, and their degree of personal confidence in, 79 their own skills, abilities and competence, the ability in individuals to recognise opportunities, 80 and fear of failure (Camelo-Ordaz et al., 2016; Kickul et al., 2008; Bandura 1989). Gender is 81 a mediating factor (Camelo-Ordaz et al. 2016; Langowitz and Minniti 2007) and EA has been 82 shown to be weaker in females (Karimi et al. 2013), but other studies have not found a gender 83 influence more generally in perceptions of entrepreneurship (Obeme et al. 2014). Therefore 84 the student's transition between entrepreneurial attitude to entrepreneurial intention to 85 exhibiting entrepreneurial behaviour is mediated by a number of interactions (see Figure 1) 86 and factors such as EKI and SL play a role.

87 Take in Figure 1

88 A multiplicity of research questions arise that are worthy of consideration, An area of 89 interest for this research was to determine the student self-reported baseline EA and then the 90 impact of a workplace placement on the student participants' self-reported EA. Work 91 placements, sometimes called "sandwich years" have featured as a part of the higher 92 education learning experience for some decades (Orrell, 2004). Little (2000) highlight that 93 with a work placement as part of a wider curriculum framework, specific learning outcomes 94 can be mapped against the experience in terms of skills development such as personal and 95 social skills, problem solving, organisation skills and communication. Little and Harvey 
96 (2006) in their work on the role and value of work placements conclude that a work

97 placement offers opportunity for personal development i.e. increasing confidence and 98 interpersonal skills, better organisational, team work and time-management skills; more self99 awareness and more self-criticality and also opportunity to increase subject knowledge. 100 However the Little and Harvey (2006) study highlights specifically that a work placement had 101 helped to inform student's future intentions and career plans at the end of their programme, 102 which is a focus too of the empirical study described in this paper, As such work placement 103 experience is situated and also an opportunity to "learn in context" (Brown et al. 1989; by 104 Crebert et al. 2004). The international work critiqued in this paper has been undertaken in the 105 UK (see also the work of Gomez et al. 2004); Malaysia (e.g. Ishmail et al. 2015; Ambad and 106 Damit, 2016 among others), the US and Australia. Thus it can be argued that work placement 107 can contribute to both EKI and SL (see Figure 1). Figure 1 has been drawn together to 108 demonstrate the overall relationship within the entrepreneurial behavioural model proposed 109 by the authors. This research just considers the first element the dynamic between SL, EKI 110 and EA.

111 The baseline level of student EA may be influenced by either the learning 112 opportunities afforded at the land-based university in the preceding study years before their 113 placement, their individual personal characteristics and/or the family context where in the past 114 entrepreneurial characteristics have been evidenced. The work placement can also provide 115 alternative social networks and access to capital and informational resources that will also 116 provide a springboard for the student's future career. The student body approach to work 117 placement will be differentiated. Whilst some students may be influenced by either 118 entrepreneurial legacy and/or entrepreneurial bridging others conversely may not. This will 119 affect, both them as individuals and also as a collective group in terms of their development 120 within the education setting and the way they personally interact with the learning experience 
121 and the subject studied and the associated placement opportunities on offer could influence

122 the change in EA. The interaction between EA, PBC or PRS is unclear as well as the

123 influence of additional factors such as fear of failure, risk tolerance or risk aversion in terms

124 of future employment (Camelo-Ordaz et al. 2016; Ismail et al. 2015). The experience and

125 knowledge gained during their work placement year may therefore influence EA in either a

126 positive or a negative way. The main aim of the research was to consider the research

127 question: Does undertaking a work placement influence student entrepreneurial 128 attitudes (EA)?

129 Thus this research has been designed to consider four hypotheses:

$130 \quad$ H1 Gender influences baseline student EA.

$131 \quad$ H2 Gender influences the increase in student EA during work placement.

$132 \quad$ H3 Undertaking a work placement during a university course increases student EA.

$133 \quad$ H4 There is a difference in baseline student EA in line with course studied.

134 The paper is constructed as follows: firstly literature is used to provide context, secondly the 135 methodology is explained; the results are analysed and discussed and finally conclusions 136 drawn.

137 3. Method

138 The methodology used for this research was an intrinsic case study approach within 139 the boundaries of issues of student work placement and self-reported EA. The data was 140 collected in October 2016 at Harper Adams University, which is a specialist university for the 141 land-based sector. Annually a multi-method survey approach is used to collect both 142 qualitative and quantitative post work placement data in order to capture feedback from the 143 students themselves relating to preparation for and support on placement. This data forms part 144 of the course monitoring approach used in the university and students are actively encouraged 145 to complete survey. 
The sample population comprised of a group of students who had recently returned

147 from a 44-52 week compulsory placement period $(n=461)$ and were returning to their final 148 year of study. Table 1 shows the profile of the survey population. The numbers surveyed on 149 the Agriculture courses are subdivided by undergraduate BSc Honours degree course (four 150 year including placement in the third year) or by FdSc Foundation degree course, a three year 151 course with the placement in the second year of study. Specific questions relating to EA were 152 included in the survey. The survey was completed anonymously and, in the instances where 153 some respondents chose to not answer a given question, actual respondent frequencies of 154 completion are shown in the results section to overcome differences in reporting frequency 155 compared to the whole sample data set. Questions relating to EA before and after placement 156 used a ten point scale where $1=$ being no EA and $10=$ being a high level of EA and the 157 intention to start their own business or develop an existing business when the student leaves 158 University and commences work.

\section{Take in Table 1}

160 The responses were part of a formal process of feedback and reflection following the 161 work placement. A limitation of the study is that the students may have responded as a matter 162 of routine amongst a series of questions. As the students know, albeit that the work placement 163 receives a simple pass/fail mark that the completion of the questionnaire forms part of their 164 formal obligations to the university and this may have led to some response bias. However the 165 research has been carried out to provide context and to frame further research in this area with 166 regard to students' EA. Although the sampling method was convenience sampling, the 167 researchers feel that as long as the results are interpreted within this in mind then the 168 conclusions drawn in the paper have validity. Descriptive analysis of the data was undertaken 169 using the calculation of a mean score for each factor. This gives statistical significance of $17090 \%$ confidence with $+/-5 \%$ accuracy (West, 1999). Inferential statistical analysis 
(independent samples t-test) was used to consider statistical significance and is reported at

$172 \quad(\mathrm{p}<0.05)$.

173

174

4. Results

175

The response rate was $98.7 \%$. The reason for this high response level is that all

176 students were required to complete the survey on their return from placement. The

177 respondents were asked to give an indication of their gender and $2.4 \%$ declined to identify

178 their gender for the survey $(n=444)$. Of those who reported gender for the whole survey there

179 was an even split of males to females (49.5:50.5). Respondents did not answer all questions

180 so gender response is subsequently reported by question. Student views on the impact of

181 placement on their entrepreneurial attitudes were collated via the following question:

182 'Please rank your entrepreneurial attitudes before and after the placement based on a scale

183 of 1 to 10 (1 being no entrepreneurial attitude and 10 being you have a high level of

184 entrepreneurial attitude and you intend to start your own business or develop an existing

185

business when you leave Harper Adams and start work).

186 The weighted mean scores for the respondents to this question $(n=455)$ for this 187 question has been analysed by whole survey and by gender (Table 3) in order to test and gain 188 further understanding of hypothesis: H1: Gender influences baseline student EA.

189 Male students showed a greater EA pre-placement than females (score 5.66 and 4.61 190 respectively). However, it is interesting to note, that whilst the weighted mean post placement 191 for females is less than that of the males (6.99 compared with 7.68), the females show a 192 greater overall difference in EA post placement with a weighted mean difference of 2.38 193 compared to the whole survey sample (2.19). The results demonstrate (Table 2) that for the 194 weighted mean average the male students were more likely to intend to start their own 195 business or develop an existing business before placement than females concurring with 196 Ambad and Damit, (2016), and Karimi et al. (2013). Using the independent samples t-test 
197 demonstrated there was a statistically significant difference at $p<0.05$ with regards to gender 198 and that males had a higher baseline EA than females. This proves H1 in the context of this 199 university. This study has also shown that gender influences baseline weighted mean student 200 EA with females having a lower baseline weighted mean EA (H1), that gender too influences 201 the difference in weighted mean EA before and after placement with females increasing more 202 in weighted mean EA during a placement activity agreeing with Karimi et al. (2013) and 203 others. There is also a difference in weighted mean baseline EA in line with courses studied 204 as well as the proportion of increased weighted mean EA on different courses (H4).

\section{Take in Table 2}

The research also tested: H2: Gender influences the increase in student EA during

work placement.

208

As previously described, the data in Table 2 demonstrates that increase in weighted 209 mean average for females (2.38) was greater than males (2.02) thus proving H2. The 210 difference in weighted mean before placement (1.05) between males and females narrowed 211 after placement to (0.69). Using the independent samples t-test to analyse the increase in EA 212 during work placement showed there was a statistically significant difference at $\mathrm{p}<0.05$ with 213 regards to gender with work placement having a greater positive influence on females than 214 males, but this in part could be due to males having a higher baseline EA. Karimi et al. (2013) 215 considered the gender relationship was nuanced and that whilst gender did not influence PBC 216 and EI, gender did affect firstly EA, which was weaker for females, concluding that 217 subjective norm ( $\mathrm{SN})$ was a stronger predictor of EI for female students than for male. SN is 218 the perceived social pressure, in this case for female students, to perform or not perform a 219 specific behaviour (Ajzen, 1991) in this instance, entrepreneurial behaviour. Thus it could be 220 suggested that the activities and experiences associated with a work placement may overcome previous social learning that has led females to perceive that they should not engage in 
222 entrepreneurial behaviour and this impacts their EA. This is worthy of more qualitative 223 research.

224 The third hypothesis tested in this study is H3: Undertaking a work placement 225 during a university course increases student EA. This hypothesis has also been proven in 226 this study as previously described. The results show that undertaking a work placement does 227 influence EA with an overall weighted mean EA before placement of 5.10 and after 228 placement of 7.29. This clearly demonstrates that undertaking a work placement as a learning 229 opportunity whilst at university increases weighted mean student EA (H3). Using the 230 independent samples t-test demonstrated there was a statistically significant difference at $231 \mathrm{p}<0.05$ with regards to gender and that females experienced a higher increase in EA as a 232 result of placement.

233 The fourth hypothesis tested was H4: There is a difference in baseline student EA 234 in line with course studied. The weighted mean before and after placement for individual 235 courses has been collated (Table 3). The courses have been ranked by weighted mean before 236 and after placement and by weighted mean difference and standard deviation difference.

\section{Take in Table 3}

238 Students studying on the Agricultural suite of courses showed a greater EA pre239 placement than other courses although, there were differences between those on the BSc 240 Agriculture course and FdSc Agriculture course where the weighted mean EA for the FdSc 241 students was lower than BSc students (5.28 compared to 5.81) as shown in Table 3. However, 242 the impact of the placement period for the FdSc students showed a greater weighted mean 243 difference in EA post placement than BSc Agriculture students (2.38 compared with 2.25 244 respectively).

245 Students on the Animal Behaviour, Welfare courses showed least EA pre placement, 246 but the weighted mean difference in EA post placement (2.29) highlighted the influence of the 
247 placement experience. The students on the Agriculture BSc course, Vet Physiotherapy, Rural 248 Estate Management and Engineering showed the greatest EA before placement. The Business, 249 Agri-food and Agribusiness course and the Agriculture FdSc showed the greatest increase in 250 EA during placement. The Food related courses showed the least increase in EA during 251 placement so further investigations into the types of placement activities would be of value to 252 see if there was a particular influence. The weighted mean EA difference overall for each 253 course (Table 2) shows that females reported a greater overall difference to EA post 254 placement (2.38) than males and above the average of the whole survey (2.19). On a course 255 level, students on the Agriculture FdSc course and Business, Agrifood and Agribusiness 256 courses showed greater weighted mean difference EA scores (2.38 and 2.37 respectively) than 257 students on the other courses and Food related courses specifically showed that placement had 258 the least reported impact on EA (1.76). Descriptive analysis of EA for all students on 259 agricultural courses shows a shift in EA before and after placement with a generally uniform 260 cohort before placement of students albeit with some tails that show heightened and 261 conversely lesser EA (Figure 2).

\section{Take in Figure 2}

263

Analysis of the standard deviation in EA before and after placement (Table 3) shows a 264 convergence of EA after placement for some courses (Agriculture; Business, Agrifood, 265 Agribusiness; and Countryside, Environment and Geography) and to a lesser extent Vet 266 Physiotherapy. For other courses (Engineering and Food) there is a greater divergence in EA 267 after placement, but most noticeably for Rural Estate Management and Animal Behaviour and 268 Welfare. There is a difference in the profile of students on the BSc Agriculture course before 269 and after placement in terms of EA and standard deviation which suggests a multiple 270 grouping of students in terms of EA initially, but this is much more uniform after placement 271 (Figure 3). Students on the FdSc Agriculture course show greater uniformity as a cohort in 
272 terms of EA both before and after placement although there is a recognizable tail on both

273 Agricultural courses that show a lag in reported EA (Figure 4).

274 Take in Figures 3 and 4

275 In order to explore the influence of entrepreneurial legacy on EA the respondents 276 were asked to consider their own background and identify whether they came from a 277 background of family business/self-employment and this is shown in Table 4. The 278 respondents who answered this question $(n=449)$ reported that two thirds $(65.3 \%)$ came from 279 a background of family business and/or self-employment. There was a slight gender influence 280 with males coming from this background (67\%) and females (64.7\%). There was however a 281 greater bias towards a family background of self-employment in terms of Business, Agrifood 282 and Agribusiness courses (77.8\%) Agricultural courses (77.2\%) with little difference between 283 the BSc and the FdSc courses); Food related courses (76.9\%) and Rural Estate Management 284 (68.4\%). This compared with students on the Engineering, Vet Physiotherapy, Animal 285 Behaviour and Welfare, and Countryside, Environment and Geography courses that reported 286 a lesser background in self-employment (57.5\%, 53.8\%; 40.6 \%and 37.8\% respectively).

\section{Take in Table 4}

288 Those respondents who answered that they came from a background of family 289 business/self-employment, were subsequently asked whether it had shaped their views on 290 themselves starting a business or developing a business, although they were not asked to 291 identify quantitatively whether this was a positive or negative perception. Family background 292 of business or self-employment was a strong influence on shaping the views of respondents 293 who answered this question $(n=286)$ on whether they would themselves start or develop an 294 aspect of the business on all courses, with the exception of the students on the Food related 295 courses (Table 5). Overall $80.8 \%$ of respondents $(n=231)$ reported that a background of 296 family business/self- employment had shaped their views on starting a business or developing 
an existing business themselves in the future, highlighting the role of entrepreneurial legacy

298 in guiding students views on starting a business or develop an existing business. There was a 299 slight gender influence with males being more influenced by entrepreneurial legacy (83.9\%) 300 compared with females (77.5\%). There was a differentiation of entrepreneurial legacy by course studied with influence highlighted by Agricultural programmes $(90.9 \%$ for the FdSc course and $88.1 \%$ for the BSc course); and the Business, Agrifood and Agribusiness course $303(87 \%)$

\section{Take in Table 5}

305

306

307

308

309

310

Before placement, there are two distinct cohorts on the engineering course with regard to reporting of EA (Figure 5) suggesting that there is sub-group of engineering respondents who report pre-placement EA whereas there is a second group that initially have reported low levels of EA. This shows the value of the placement in shifting entrepreneurial perceptions in students on the engineering course is mixed. Within the overall number of Engineering students in the study $(n=41), 57.5 \%$ of these students stated that they came from a family background of family business or self employment $(n=23)$ and of these students $79.2 \%(n=19)$ stated that this background had influenced their EA. This suggests that there may be two distinct cohorts on the engineering course with regard to EA.

Within the overall number of Animal Behaviour, Welfare students that responded in this study ( $\mathrm{n}=64), 40.6 \%$ of these students stated that they came from a family background of family business or self employment $(n=26)$ and of these students $76.9 \%(n=10)$ stated that this family background had influenced their EA. It can be shown through this study that both before and after placement there is a greater differentiation of students with regard to EA on the Animal Behaviour, Welfare studies course compared with the Agriculture related course (Figure 6). However with a weighted mean shift of EA difference before and after placement of 2.29 there is a clear demonstration of the influence of the placement work period for 
323 students on the Animal Behaviour, Welfare studies course. The data implies that with regard

324 to reported EA, as with the engineering course, there may be multiple sub-populations within 325 the cohort of students.

326 Take in Figures 5 and 6

327 The number of students who responded that their background of family business 328 influenced their EA on the Veterinary Physiotherapy course $(n=5)$ from a small overall 329 population in the study of 14); and Countryside, Environment and Geography course ( $\mathrm{n}=9$ 330 from a sample size in the study of 37) limited any further interpretation with regard to the 331 impact of entrepreneurial legacy. There is a weighted mean shift of EA between before and 332 after placement of 2.28 for the Vet Physiotherapy course and a weighted mean shift of EA 333 between before and after placement of 2.08 for the Countryside, Environment and Geography 334 course again demonstrating the reported influence of the placement work period for students 335 on these two courses.

336 The Rural Estate Management students in the study $(n=56)$, reported that $68.4 \%$ came 337 from a background of family business or self employment $(n=39)$ and of these students $71.1 \%$ $338(\mathrm{n}=27)$ stated that this background had influenced their EA. The weighted mean average of 339 EA before placement was 5.39 and after placement increased to 7.32 (Figure 7). There were 340 twenty-six food students in the overall study, which makes interpretation of the trends with 341 regard to student EA limiting. However weighted mean difference in EA before and after 342 placement was lowest in this group at 1.76 (Figure 8). Whilst $76.9 \%$ of these students 343 reported that they came from a family background of family business or self employment $344(n=20)$, of these students $60 \%(n=12)$ stated that this background had influenced their EA. 345 Using the independent samples t-test to analyse the influence of family background on 346 baseline EA demonstrated that those students from a background of family business had a 347 higher baseline EA and a higher EA after placement which was statistically significant at 
$348 \mathrm{p}<0.05$. However the change in EA before and after placement between those students who

349 had a background of family self-employment and those students who did not, showed no

350 statistically significant difference at $\mathrm{p}<0.05$. All these factors are worthy of further study.

\section{Take in Figures 7 and 8 and further qualitative analysis}

352 5. Discussion

353 The main aim of the research was to consider the research question: Does undertaking a 354 work placement influence student entrepreneurial attitudes (EA).

355 A review of relevant literature informed questions incorporated in the university's annual 356 feedback questionnaire completed by students $(n=461)$ on return from a work placement of 357 between 44 and 52 weeks. The responses were reviewed and analysed in order to give an 358 insight into the EA of students before and after placement, by cohort and also the influence of 359 gender. Previous literature has highlighted that a work placement provides a situational and 360 context driven learning experience and can aid personal development, provide opportunity to 361 develop subject knowledge and also help to inform future intentions and career plans (Little, 362 2000; Crebert et al. 2004; Orrell, 2004; Little and Harvey, 2006).

363 The research explored and tested the four hypotheses that were all proven:

364 - H1 Gender influences baseline student EA.

365

- $\mathbf{H 2}$ Gender influences the increase in student EA during work placement.

- H3 Undertaking a work placement during a university course increases student EA. 2015) and potentially increased confidence in both PBC and PRS with an average background 371 of self-employment of $77.1 \%$. Students on the Animal Behaviour Welfare related courses 372 showed the least EA before placement, however, the weighted mean difference in EA post 
373 placement (2.29) was similar to Agriculture All (2.30) suggesting a similar influence from the

374 placement experience even though baseline EA and potentially the level of entrepreneurial

375 legacy (40.6\%) was different. Therefore undertaking a placement activity has been shown to 376 increase reported EA across all courses. The small sub-populations made detailed analytical 377 analysis difficult. Two important findings are that:

378

379

380

381

382

383

384

385

386

387

388

389

390

391

392

393

394

395

396

397
- Female students show lower baseline reported EA but the overall difference in reported EA post placement was greater $(p<0.05)$ and

- There was a difference noted between courses in student self-reported EA before and after placement but further work is required with a larger dataset to quantify these differences more objectively and/or see if the results are repeatable with a second student cohort.

Further research could be undertaken to consider the value of work placement to the student from a wider pedagogic framing in terms of the learned or lived experience of the work placement and its impact on EA. The influence of placement on female students overall is worthy of further qualitative study as to the exact nature of the factors that influence lower baseline EA. There are some factors identified in the literature, but an exploratory study would highlight their interaction more clearly how they interact especially how experience influences attitudinal response both before and after a work placement. Further research on the type, commonalities and differences of workplace experience by course would also be of value. This suggests that a wider exploration of pedagogic framing of the "lived learning experience" would be of value when considering the development of entrepreneurial attitude.

It would also be good to see how much pre-course work experience had been undertaken and whether this influenced baseline EA. This in part may be influenced by entrepreneurial legacy and that work experience before university in the family business or alternatively work experience in the industry in which students seek to have a career has already increased 
398 baseline EA. This might go some way to explained why on some courses such as animal 399 behaviour and geography baseline EA is lower. The specific findings for females and the 400 impact of work placement on EA should be specifically considered in terms of encouraging 401 female education opportunities. Internationally, where female education opportunities may be 402 more limited than in the country in which the study took place, pedagogic development for 403 women who can access learning via a life-long learning work based programme should also 404 be considered.

405

406 6. Conclusion

407 Entrepreneurship is vital for economic growth and entrepreneurial behavior post education 408 amongst students has been the central element of this work. The aim of the research was to 409 determine the impact of a workplace placement on the statistically more likely to report 410 higher EA than females $(\mathrm{p}<0.05)$. However, a work placement during a university course may 411 overcome social pressure, social learning and the boundaries created by subjective norms 412 prior to university for females, as in this study they report they are more likely to intend to 413 start their own business or develop an existing business after the experience of work 414 placement. The increase in reported EA after placement was greater for females and was 415 influenced by the course of study. The influence of entrepreneurial legacy in terms of self416 reported EA has also been shown.

417 Further, this study does show that the process of adapting to cultural expectations and 418 organisational pressures during a work placement (see Crebert et al. 2004), does change the 419 student's personal outlook and their attitudes towards their career destinatiofluened by 420 entrepreneurial legacy. This research also shows that the student body is not homogenous and 421 not only gender, but also previous experience, especially the social legacy of family context 422 and whether for example the student is from a family with a self-employed background, will 
423 influence both baseline and future EA. This means that how the work placement is designed, 424 implemented and mediated by the university, the student themselves and the learning 425 experience provided via the employer will play an important part in the overall experience 426 derived and the difference in baseline and completion levels of personal development and 427 self-reflection on future career intentions.

428 This study was undertaken in the UK, but has potentially wider applicability in an 429 international context with universities that undertake a placement period, with the caveats 430 outlined with regard to the student family background and how this might influence this 431 specific grouping of students. This study provides context for further qualitative and 432 quantitative work in this area to explore more fully the influence of entrepreneurial legacy on 433 EA in terms of both PBC and PRS. This work will also inform pedagogical development in 434 terms of embedding entrepreneurial teaching in future curriculum development at the 435 university. 
437

438

439

440

441

442

443

444

445

446

447

448

449

450

451

452

453

454

455

456

457

458

459

460

461

462

463

464

465

466

467

468

469

470

471

472

473

474

475

476

477

478

479

480

481

482

\section{References}

Ajzen, I. (1991), "The theory of planned behaviour", Organizational Behaviour and Human Decision Processes, Vol. 50 No. 2, pp. 179-211.

Ambad, S.N.A., and Damit, D.H.D.A. (2016), "Determinants of Entrepreneurial Intention among Undergraduate Students in Malaysia”, Fifth International Conference on Marketing and Retailing ( $5^{\text {th }}$ INCOMaR), Procedia Economics and Finance, Vol. 37, 108-114

Bandura, A., (1989). "Regulation of cognitive processes through perceived self-efficacy" Developmental Psychology, Vol. 25, Iss. 5, pp. 729-735.

Brown, J.S., Collins, A., \& Duguid, P. (1989). Situated cognition and the culture of learning. Educational Researcher, Vol. 18 78pp. 32-42.

Camelo-Ordaz, C., Diánez-González, J.P. and Ruiz-Navarro, J. (2016) "The influence of gender on entrepreneurial intention: The mediating role of perceptual factors". BRQ Business. Research Quarterly 2016, http://dx.doi.org/10.1016/j.brq.2016.03.001

Crebert, G., Bates, M., Bell, B., Patrick, C.J. and Cragnolini, V., (2004). Developing generic skills at university, during work placement and in employment: graduates' perceptions.

Higher Education Research \& Development, Vol. 23, Iss. 2 pp.147-165.

Dahalan, N., Jaafar, M., Asma, S., and Rosdi, M. (2013), "Local community readiness in entrepreneurship: Do gender differ in searching business opportunity", PSU-USM International Conference on Humanities and Social Sciences, Procedia-Social and Behavioral Sciences Vol. 91, pp. 403 - 410

Ehrlich, E., (1986), “America Expects too Much from Its Entrepreneurial Heroes” Business Week (July 28): pp. 33.

Gomez, S., Lush, D. and Clements, M., 2004. Work placements enhance the academic performance of bioscience undergraduates. Journal of Vocational Education and Training, Vol. 53, Iss. 3, pp.373-385.

Hébert, R.F. and Link, A.N (1988), The Entrepreneur: Mainstream Views \& Radical Critiques. New York, USA: Praeger.

Ishmail, K., Anuar, M.A., Omar, W.Z.W., Aziz, A.A., Soehod, K., Akhtar, C.S., (2015), "Entrepreneurial Intention, Entrepreneurial Orientation of Faculty and Students towards Commercialization", $3{ }^{\text {rd }}$ International Conference on Leadership, Technology and Innovation Management, Procedia - Social and Behavioral Sciences, Vol. 181, 349 - 355

Jaskiewicz, P., Combs, J.G., and Rau, S.B. (2015), "Entrepreneurial legacy: Towards a theory of how some family firms nurture transgenerational entrepreneurship", Journal of Busines venturing, Vol. 30, pp. 29-49

Karimi, S., Biemans, H.J.A., Lans, T., Chizari, M., Mulder, M., Mahdei, K.N. (2013), "Understanding role models and gender influences on entrepreneurial intentions among college students," 3rd World Conference on Learning, Teaching and Educational Leadership (WCLTA-2012), Procedia - Social and Behavioral Sciences, Vol. 93, pp. 204-214 
483 Kickul, J., Wilson, F., Marlino, D., Barbosa, S.D., (2008), “Are mis- alignments of 484 perceptions and self-efficacy causing gender gaps in entrepreneurial intention among our 485 nation's teens?" Journal of Small Business and Enterprise Development, Vol. 5 Iss. 2, pp. 486 321-335.

487

488 Korsgaard, S., Müller, S. and Wittorff Tanvig, H. (2015) "Rural entrepreneurship or 489 entrepreneurship in the rural - between place and space", International Journal of 490 Entrepreneurial Behavior \& Research, Vol. 21 Iss: 1, pp.5 - 26

491

492

493

494

495

496

497

498

499 Little, B. and Harvey, L., (2006). Learning through work placements and beyond. In A report

500 for HECSU and the Higher Education Academy's Work Placements Organisation Forum.

501

502

503

504

505

506

507

508

509

510

511

Langowitz, N., and Minniti, M., (2007). "The entrepreneurial propensity of women".

Entrepreneuship Theory and Practice. Vol. 31 No. 3 pp. 341-364.

Lans, T., Blok, V., Wesselink, R. (2014), "Learning apart and together: towards an integrated competence framework for sustainable entrepreneurship in higher education", Journal of Cleaner Production, Vol. 62, pp. 37-47

Little, B., 2000, 'Undergraduates' work based learning and skills development', Tertiary Education and Management, Vol. 6, pp. 119-35.

Mat, S.C., Maat, S.M., and Mohd, N., (2015), "Identifying Factors that affecting the entrepreneurial intention among engineering technology students", $2^{\text {nd }}$ Global Conference on Business and Social Science - 2015, GCBSS-2015 17-18 September 2015, Bali, Indonesia, Procedia - Social and Behavioral Sciences Vol. 211, pp. 1016-1022

512

Obembe, E., Otesile, O., and Ukpong, I. (2014), “Understanding the students' perspectives towards entrepreneurship", ICGSM 2014, Procedia - Social and Behavioral Sciences, Vol.

513 Orrell, J., 2004, July. Work-integrated learning programmes: Management and educational 514 quality. In Proceedings of the Australian Universities Quality Forum (pp. 76-80). Victoria:

515 Victoria University.

516

517

518

519

520

521

522

523

524

West, C. (1999) Marketing research. MacMillan Business Masters. Basingstoke: MacMillan Press Ltd.) 


\section{List of Tables}

\section{6}

527

528

529

530

531

532

533

534

535

536

537

538

539

540

541

542

543

544

545

546

547

548

549
Table 1. Survey Profile

Table 2. Gender profile and difference in weighted mean EA before and after work placement

Table 3. Course profile and difference in weighted mean EA before and after work placement

Table 4. Reported background of family business/self- employment

Table 5. Has a background of family business/self- employment shaped your views on yourself starting a business or developing an existing business?

\section{List of Figures}

Figure 1. Environmental behaviour model

Figure 2. EA of students on all Agricultural courses before and after placement.

Figure 3. EA of students on the BSc Agricultural course before and after placement.

Figure 4. EA of students on the FdSc Agricultural course before and after placement.

Figure 5. EA of students on the BSc Engineering course before and after placement.

Figure 6. EA of students on the BSc Animal Behaviour Welfare course before and after placement.

Figure 7. EA of students on the BSc Rural Estate Management course before and after placement.

Figure 8. EA of students on the BSc Food related course before and after placement 
Table 1. Survey Profile

\begin{tabular}{|l|l|l|}
\hline Course of study & Number & \% \\
\hline Agriculture (All) & 140 & 30.37 \\
\hline \multicolumn{1}{|c|}{ Agriculture- BSc } & 79 & 17.14 \\
\hline \multicolumn{1}{|c|}{ Agriculture- FdSc } & 61 & 13.23 \\
\hline Business, Agrifood, Agribusiness. & 73 & 15.84 \\
\hline Rural Estate Management & 66 & 14.32 \\
\hline Animal Behaviour, Welfare & 64 & 13.88 \\
\hline Engineering & 41 & 8.89 \\
\hline Countryside, Environment, Geography & 37 & 8.03 \\
\hline Food related & 26 & 5.64 \\
\hline Vet Physiotherapy & 14 & 3.04 \\
\hline Whole Survey Total & $\mathbf{4 6 1}$ & \\
\hline
\end{tabular}

551

557

558

559

560

561

562

563

564

565

566

567

*Note the number is the number of respondents to the survey, not the number studying on the course.

Table 2. Gender profile and difference in weighted mean EA before and after work placement

\begin{tabular}{|l|l|l|l|l|l|}
\hline & $\begin{array}{l}\text { Number of } \\
\text { respondents }\end{array}$ & $\begin{array}{l}\text { \% Number } \\
\text { of } \\
\text { respondents }\end{array}$ & $\begin{array}{l}\text { Weighted } \\
\text { mean EA } \\
\text { before } \\
\text { placement }\end{array}$ & $\begin{array}{l}\text { Weighted } \\
\text { mean EA } \\
\text { after } \\
\text { placement }\end{array}$ & $\begin{array}{l}\text { Weighted } \\
\text { mean } \\
\text { difference }\end{array}$ \\
\hline Whole Survey & 445 & 100 & 5.10 & 7.29 & 2.19 \\
\hline Females & 217 & 47.69 & 4.61 & 6.99 & 2.38 \\
\hline Males & 214 & 47.03 & 5.66 & 7.68 & 2.02 \\
\hline
\end{tabular}

*The whole survey includes those who reported as female $(\mathrm{n}=217)$; male $(\mathrm{n}=214)$ and those who preferred not to say $(\mathrm{n}=14)$ 


\section{Table 3. Course profile and difference in weighted mean EA before and after work} placement

\begin{tabular}{|c|c|c|c|c|c|c|c|}
\hline $\begin{array}{c}\text { Profile and } \\
\text { related course }\end{array}$ & $\begin{array}{l}\text { Number } \\
\text { surveyed }\end{array}$ & $\begin{array}{l}\text { Number of } \\
\text { respondents }\end{array}$ & $\begin{array}{c}\% \text { Number of } \\
\text { overall } \\
\text { respondents }\end{array}$ & $\begin{array}{c}\text { Weighted } \\
\text { mean EA } \\
\text { before } \\
\text { placement }\end{array}$ & $\begin{array}{c}\text { Weighted } \\
\text { mean EA } \\
\text { after } \\
\text { placement }\end{array}$ & $\begin{array}{l}\text { Weighted } \\
\text { mean } \\
\text { difference }\end{array}$ & $\begin{array}{c}\text { SD } \\
\text { difference }\end{array}$ \\
\hline Whole Survey & 461 & 445 & 100 & $\begin{array}{l}5.10 \\
\text { (SD 1.95) }\end{array}$ & $\begin{array}{l}7.29 \\
\text { (SD 1.87) }\end{array}$ & 2.19 & 0.08 \\
\hline $\begin{array}{l}\text { Agriculture (All } \\
\text { students) }\end{array}$ & 140 & 139 & 31.24 & $\begin{array}{l}5.58 \\
\text { (SD 1.85) }\end{array}$ & $\begin{array}{l}7.88 \\
\text { (SD 1.48) }\end{array}$ & 2.30 & 0.37 \\
\hline Agriculture- BSc & 79 & 78 & 17.53 & 5.81 & 8.06 & 2.25 & \\
\hline Agriculture- FdSc & 61 & 61 & 13.71 & 5.28 & 7.66 & 2.38 & \\
\hline $\begin{array}{l}\text { Business, } \\
\text { Agrifood, } \\
\text { Agribusiness }\end{array}$ & 73 & 73 & 16.40 & $\begin{array}{l}5.12 \\
(\mathrm{SD} 2.00)\end{array}$ & $\begin{array}{l}7.49 \\
(1.76)\end{array}$ & 2.37 & 0.24 \\
\hline $\begin{array}{l}\text { Rural Estate } \\
\text { Management }\end{array}$ & 66 & 56 & 12.58 & $\begin{array}{l}5.39 \\
\text { (SD 1.99) }\end{array}$ & $\begin{array}{l}7.32 \\
(2.34)\end{array}$ & 1.93 & -0.35 \\
\hline $\begin{array}{l}\text { Animal } \\
\text { Behaviour, } \\
\text { Welfare }\end{array}$ & 64 & 64 & 14.38 & $\begin{array}{l}3.91 \\
\text { (SD 1.93) }\end{array}$ & $\begin{array}{l}6.20 \\
(2.30)\end{array}$ & 2.29 & -0.37 \\
\hline Engineering & 41 & 37 & 8.31 & $\begin{array}{l}5.38 \\
\text { (SD 1.67) }\end{array}$ & $\begin{array}{l}7.32 \\
\text { (SD 1.82) }\end{array}$ & 1.94 & -0.15 \\
\hline $\begin{array}{l}\text { Countryside, } \\
\text { Environment, } \\
\text { Geography }\end{array}$ & 37 & 36 & 8.09 & $\begin{array}{l}4.53 \\
\text { (SD 2.20) }\end{array}$ & $\begin{array}{l}6.61 \\
\text { (SD 1.96) }\end{array}$ & 2.08 & 0.24 \\
\hline Food & 26 & 26 & 5.84 & $\begin{array}{l}5.12 \\
\text { (SD 1.66) }\end{array}$ & $\begin{array}{l}6.88 \\
\text { (SD 1.76) }\end{array}$ & 1.76 & -0.10 \\
\hline Vet Physiotherapy & 14 & 14 & 3.08 & $\begin{array}{l}5.36 \\
\text { (SD 1.99) } \\
\end{array}$ & $\begin{array}{l}7.64 \\
\text { (SD 1.95) }\end{array}$ & 2.28 & 0.04 \\
\hline
\end{tabular}

Table 4. Reported background of family business/self- employment

\begin{tabular}{|l|c|c|c|c|}
\hline \multicolumn{1}{|c|}{ Profile and related course } & Yes & $\mathbf{\%}$ & No & $\mathbf{\%}$ \\
\hline Whole Survey Total & 293 & 65.30 & 156 & 34.70 \\
\hline Females & 141 & 64.70 & 77 & 35.30 \\
\hline Males & 146 & 67.00 & 72 & 33.00 \\
\hline & & & & \\
\hline Business, Agrifood, Agribusiness & 56 & 77.80 & 16 & 22.20 \\
\hline Agriculture- BSc & 61 & 77.20 & 18 & 22.80 \\
\hline Agriculture- FdSc & 47 & 77.00 & 14 & 23.00 \\
\hline Food related & 20 & 76.90 & 6 & 23.10 \\
\hline Rural Estate Management & 39 & 68.40 & 18 & 31.60 \\
\hline Engineering & 23 & 57.50 & 17 & 42.50 \\
\hline Vet Physiotherapy & 7 & 53.80 & 6 & 46.20 \\
\hline Animal Behaviour, Welfare & 26 & 40.60 & 38 & 59.40 \\
\hline Countryside, Environment, Geography & 14 & 37.80 & 23 & 62.20 \\
\hline *Respondent who did not report gender for this question was $\mathrm{n}=6$ & & & \\
\end{tabular}

572 *Respondent who did not report gender for this question was $n=6$ 
573 Table 5. Has a background of family business/self- employment shaped your views on 574 yourself starting a business or developing an existing business?

575

576

\begin{tabular}{|l|l|l|l|l|}
\hline \multicolumn{1}{|c|}{ Profile and related course } & \multicolumn{1}{|c|}{ Yes } & \multicolumn{1}{c|}{$\%$} & \multicolumn{1}{c|}{ No } & \multicolumn{1}{c|}{$\%$} \\
\hline Whole Survey Total & 231 & 80.80 & 55 & 19.20 \\
\hline Females & 107 & 77.50 & 31 & 22.50 \\
\hline Males & 120 & 83.90 & 23 & 16.10 \\
\hline & & & & \\
\hline Agriculture- FdSc & 40 & 90.90 & 4 & 9.10 \\
\hline Agriculture- BSc & 52 & 88.10 & 7 & 11.90 \\
\hline Business, Agrifood, Agribusiness & 47 & 87.00 & 7 & 13.00 \\
\hline Engineering & 19 & 79.20 & 5 & 20.80 \\
\hline Animal Behaviour, Welfare & 20 & 76.90 & 6 & 23.10 \\
\hline Vet Physiotherapy & 5 & 71.40 & 2 & 28.60 \\
\hline Rural Estate Management & 27 & 71.10 & 11 & 28.90 \\
\hline Countryside, Environment, Geography & 9 & 64.30 & 5 & 35.70 \\
\hline Food related & 12 & 60.00 & 8 & 40.00 \\
\hline
\end{tabular}

*Respondent who did not report gender for this question was $n=4$ 
Figure 1. Entrepreneurial Behaviour Model
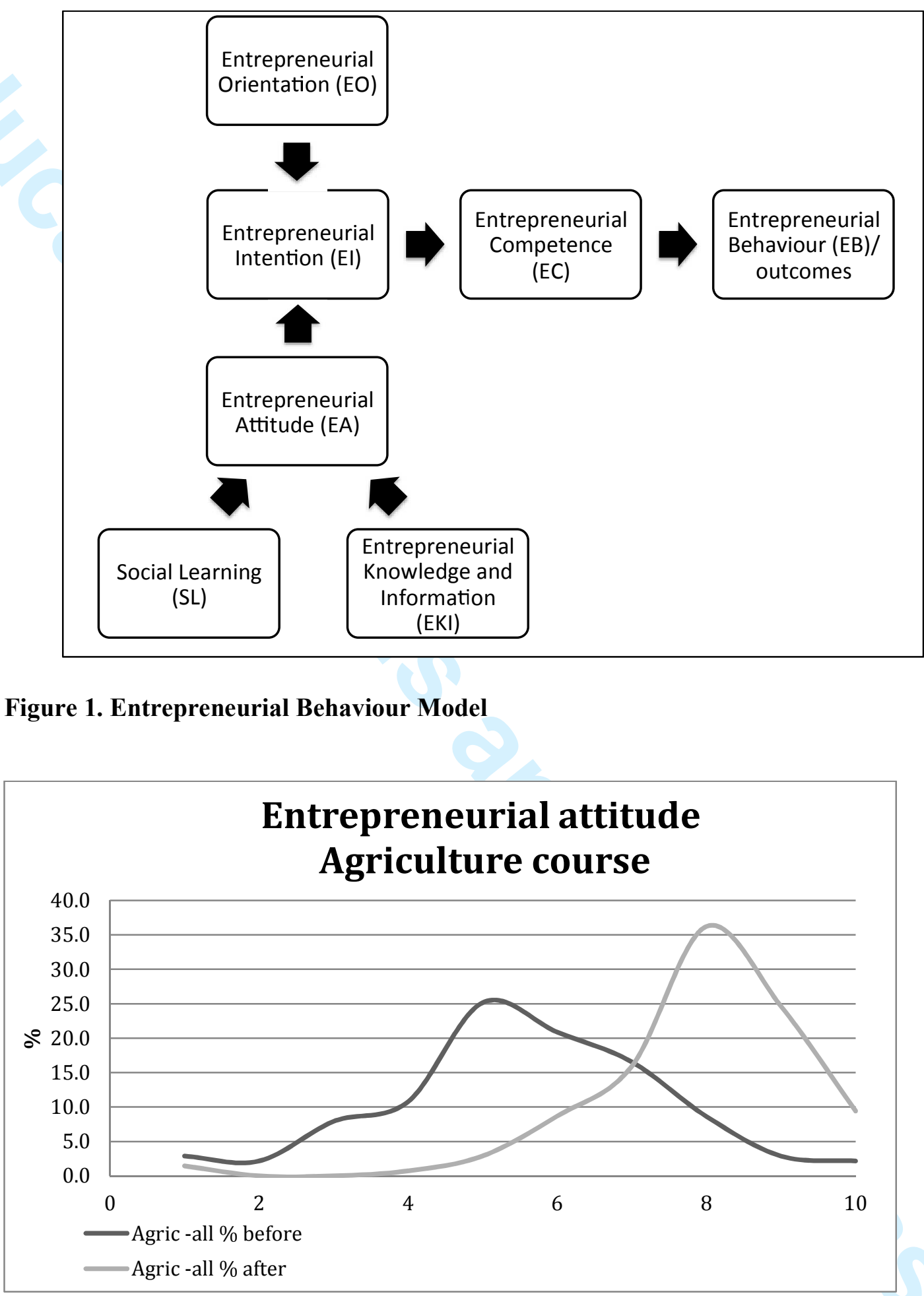

584 Figure 2. EA of students on all Agricultural courses before and after placement. 585 


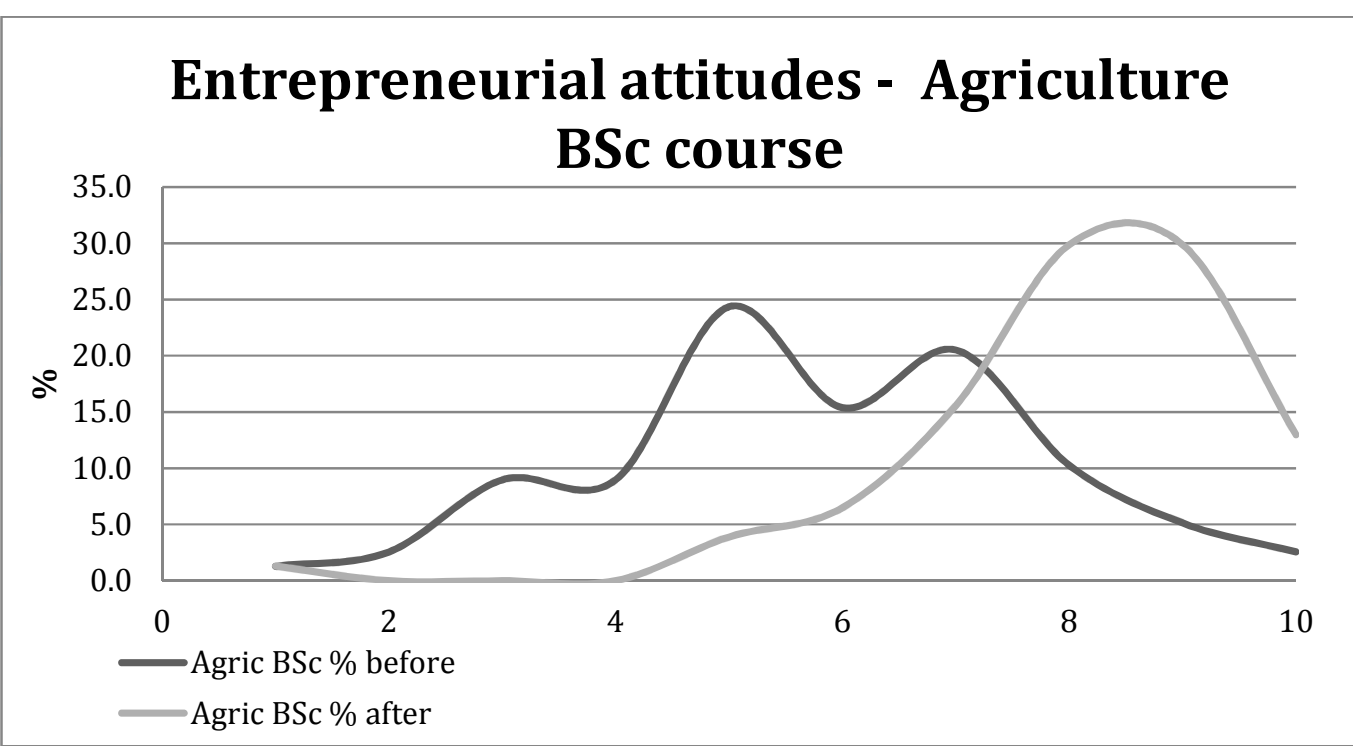

Figure 3. EA of students on the BSc Agricultural course before and after placement. 588

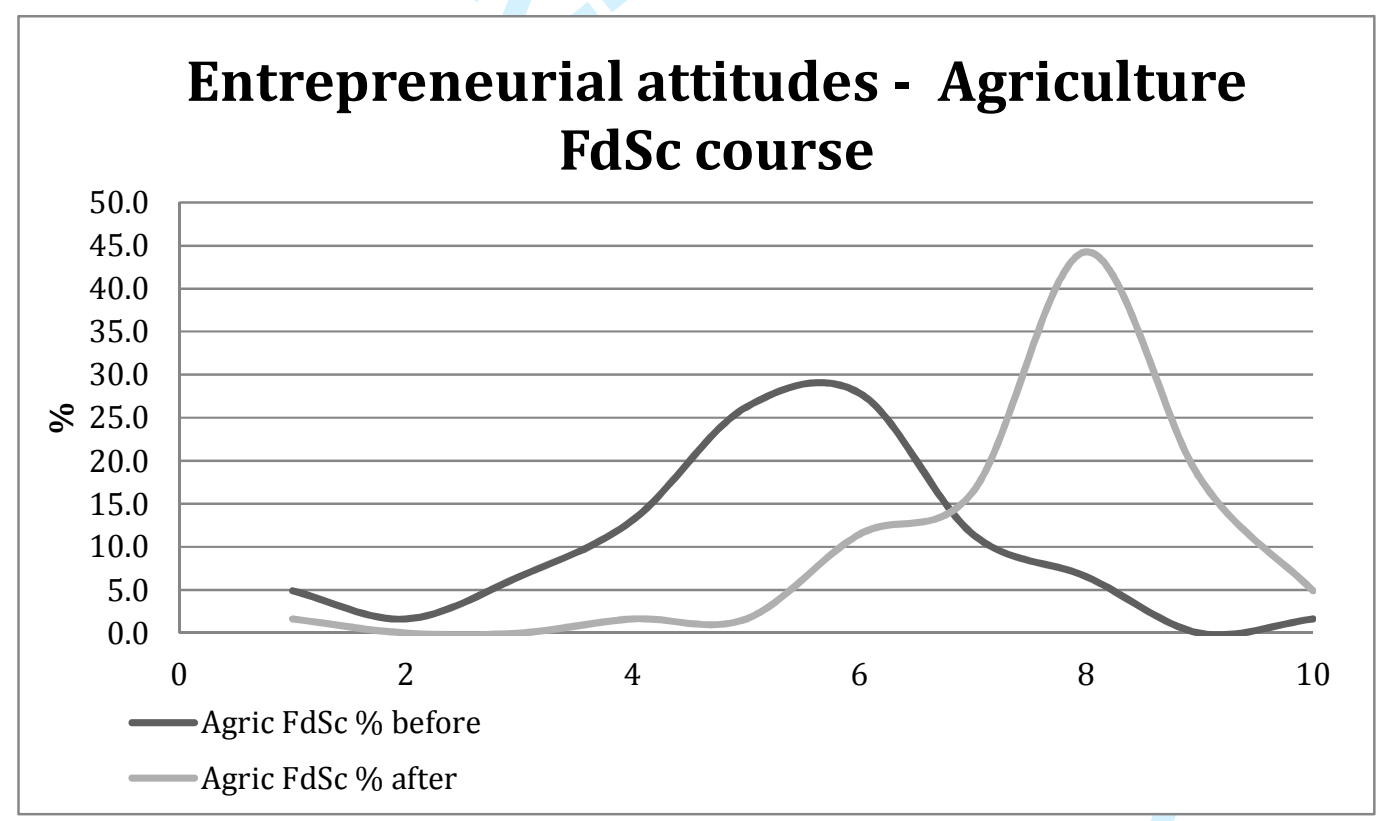

590 Figure 4. EA of students on the FdSc Agricultural course before and after placement. 
Figure 5. EA of students on the BSc Engineering course before and after placement.

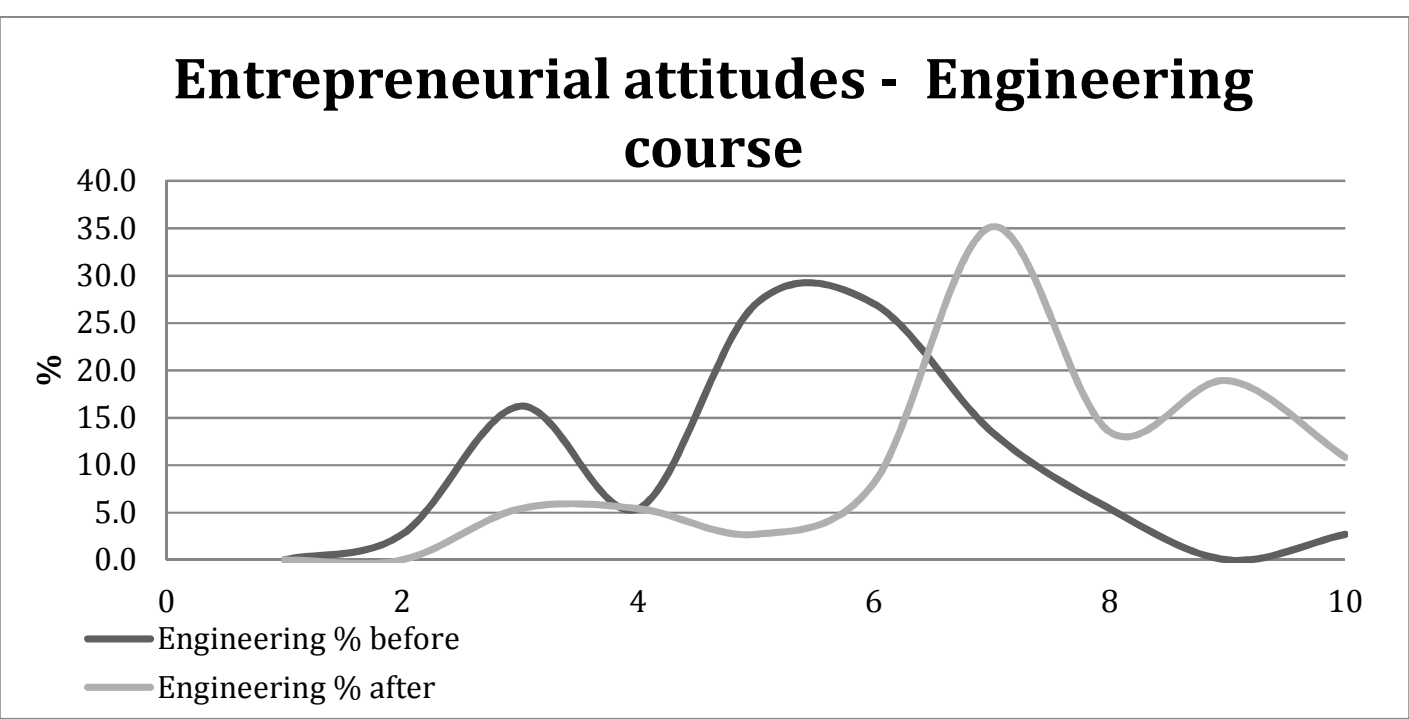

\section{6} 597 598

599

600 601

Figure 6. EA of students on the BSc Animal Behaviour Welfare course before and after placement.

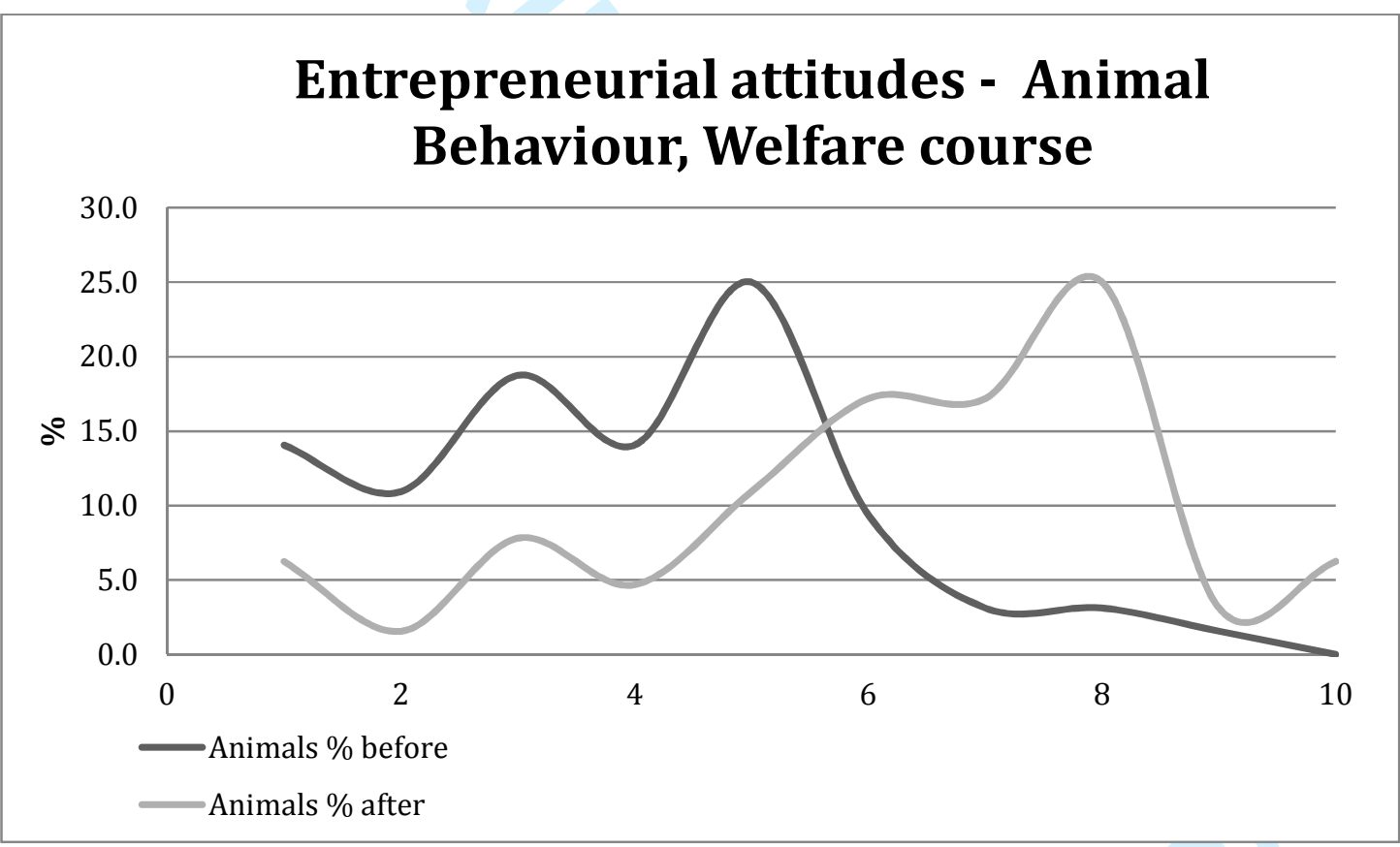




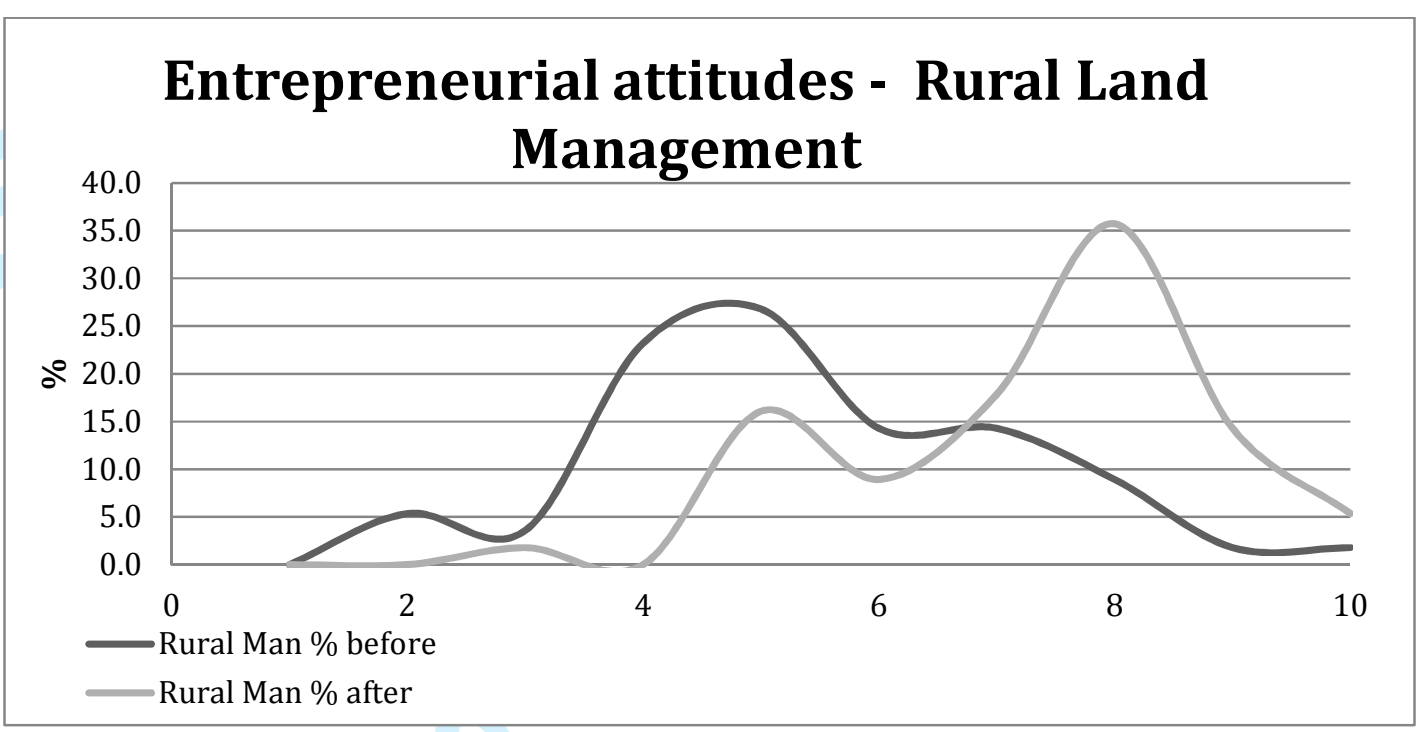

603 Figure 7. EA of students on the BSc Rural Estate Management course before and after 604 placement.

605

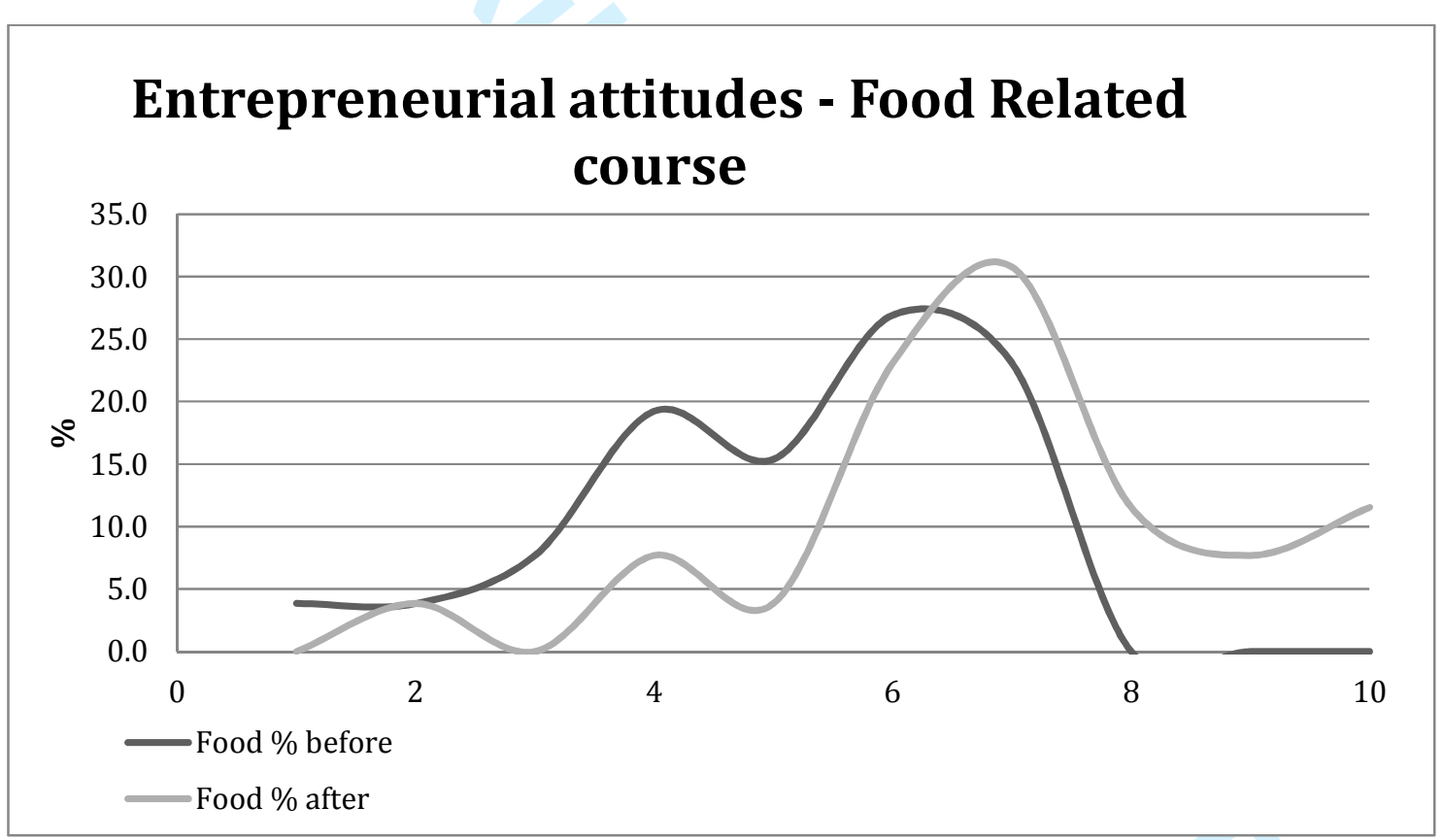

606

607

Figure 8. EA of students on the BSc Food related course before and after placement 608

609

610

611

612

613 